\title{
IMÁGENES TEATRALES EN LA PINTURA DE VASOS GRIEGOS
}

\author{
Cora Dukelsky* \\ Ana María Martino*
}

\begin{abstract}
DUKELSKY, C.; MARTINO, A.M. Imágenes teatrales en la pintura de vasos griegos. Rev. do Museu de Arqueologia e Etnologia, São Paulo, 12: 71-79, 2002.
\end{abstract}

RESUMO: A análise da pintura sobre cerâmica elaborada a partir das obras de teatro grego nos permite reconstruir, em parte, a visão do espectador dessa sociedade. Da mesma forma que na palavra escrita, as diferenças são notórias entre as imagens da tragédia e as da comédia. São especialmente atraentes as figuras grotescas e disformes que foram realizadas em consonância com a irreverência e a desenvoltura próprias do "cômico". Outro aspecto interessante é constituído pelo tema dos atores que representam papéis femininos.

\section{UNITERMOS: Teatro-Pinturas - Comédia-Tragédia-Masculino-feminino.}

El mundo griego con su complejidad y su riqueza es, sin lugar a dudas, uno de los pilares fundantes de nuestra cultura. El teatro es una de sus manifestaciones más conocidas y ha tenido la fortuna de perdurar en el tiempo, como un anclaje de la memoria de esa sociedad que supo transmitir a través de este arte, sus pensamientos y sentimientos más profundos. Este género literario que generalmente utilizó el mito como carril conductor de un elaborado sistema simbólico referente a las estructuras arquetípicas humanas, fue una de las experiencias más enriquecedoras de la humanidad. Su eterna vigencia hace posible que, a pesar de los siglos transcurridos, nosotros, como espectadores, podamos revivir las instancias con la misma fuerza con que lo hicieron los antiguos griegos. Sus orígenes ditirámbicos y rituales dejaron su huella, pero cuando ya adquiere sus características clásicas, lo encontramos en un ámbito espacial que sólo tiene un recuerdo cultual; su partido arquitectónico estádesarrollado teniendo como premisas constructivas

(*) Universidad de Buenos Aires. Argentina. todo aquello que permita el mejor desenvolvimiento de la escena y una óptima recepción por parte del público. El teatro era uno de los monumentos característicos de toda ciudad griega, jugó un rol tan importante como el templo o el ágora. Instalado al aire libre, las laderas de la colinas permitían la sustentación y el armado de las gradas donde se ubicaban los espectadores, quienes gozaban de una visión general de lo que acontecía en el escenario y la orquesta, así como de una perfecta audición, ya que los arquitectos lograron crear una excelente acústica. Estrechamente vinculado al paisaje, nunca fue un edificio totalmente autónomo sino una adaptación directa de lugares existentes a nuevas necesidades. Las primitivas danzas corales en honor a Dionisos que se hacían espontáneamente y al aire libre fueron reemplazadas por representaciones cuyo texto y escenificación se planificaron cuidadosamente, de modo que se hizo necesario un ámbito espacial acorde con las nuevas exigencias.

Los testimonios sobre el teatro griego no se reducen al aspecto literario o al arquitectónico, otro elemento más nos permite reconstruir aquellas escenas: la pintura de vasos. Las imágenes que 
decoran la cerámica constituyen un retorno visual hacia múltiples aspectos del teatro antiguo, mediante ellas podemos recrear escenarios, vestimentas, canto y baile. Ciertas características definen a una pintura como teatral: la presencia de máscaras, los disfraces, partes de escenarios $y$, a veces, inscripciones con el nombre de los personajes. Las más antiguas representaciones que se vinculan con seguridad al teatro son las de los miembros del coro, fácilmente identificables por sus disfraces de sátiros o de animales varios. Posiblemente sea un coro ditirámbico el que nos muestra un vaso de figuras negras del Pintor de Berlín $1686^{1}$ realizado alrededor del 540 a.C. Tres jóvenes, con extraños gorros orejudos, cabalgan sobre otros tres hombres con máscaras caballunas frente a un tocador de aulos. La combinación con animales es frecuente, en coincidencia con los testimonios literarios que recuerdan coros de pájaros, insectos y otras criaturas. Los "bailarinespájaro" del Pintor de Gela, ${ }^{2}$ del año 480 a.C. lucen plumas en sus cabezas y las alas, mientras el cuerpo aparece salpicado de motitas blancas muy similares al atuendo del Paposileno, ${ }^{3}$ también él estrechamente vinculado al ámbito dramático. La identificación de los coreutas con el séquito dionisíaco puede verse, además, en la actitud danzarina que, en esta obra al igual que en la anterior, está acompañada por un intérprete de aulos. La música y el baile constituían componentes esenciales del espectáculo de la misma manera que lo eran en los rituales dionisíacos; múltiples representaciones vinculadas al dios del vino muestran a los sátiros bailando al son del aulos, instrumento del delirio y las pasiones orgiásticas. Sátiros y silenos, salvajes y primitivos habitantes de los bosques asociaron sus bailes desenfrenados a antiguos rituales de fertilidad que dieron origen al teatro. Los modos de representación permiten diferenciar a un sátiro mítico del coreuta disfrazado como tal. Los pintores de vasos arcaicos como el Pintor de Amasis, el Pintor de Kleofrades, Macrón o Douris pintan sátiros "reales" desnudos, itifálicos, con orejas puntiagudas, nariz chata, cabellos desordenados, cola de caballo y a punto

(1) "Coro de caballeros disfrazados como caballos". Pintor de Berlín 1686. Ver ilustración en Bieber (1939, Fig. 79). (2) "Bailarines-pájaro". Pintor de Gela. Ilustración en Bieber (1939, Fig. 76) o Green and Handley (1995, $n^{\circ} 3$ ). (3) Observar la crátera del Pintor de la Fiala: Hermes entrega a Dionisos niño al Paposileno, 440-430 a.C. Reproducida en Charbonneaux et al. (1970, Figs. 296 y 297). de satisfacer sus instintos con reticentes Ménades. Sus actitudes exageradas se alejan del ideal del equilibrio y la racionalidad típicamente humanos. El Pintor de Pronomos ${ }^{4}$ nos muestra a los miembros del coro remedando la bestialidad satírica a través de movimientos exaltados y del disfraz: máscara con orejas y nariz animal y un taparrabos peludo, sobre el cual se sujetaba un falo erecto y una cola de caballo. En la crátera del Pintor de los Nióbidas ${ }^{5}$ del 460-50 a.C. los coreutas bailan animadamente al son de la doble flauta, podemos suponer que se mueven con entusiasmo alrededor de la orquesta. Contrastan con los desplazamientos solemnes de los dioses y con Pandora, inmóvil, en el registro superior. En realidad no debiéramos hablar de Pandora sino del actor que la personifica, recordemos que en el teatro griego no hay actrices; los roles femeninos los asumen actores disfrazados. Probablemente este vaso se refiera al drama satírico de Sófocles, Pandora, hoy perdido. El Pintor del Cíclope nos brinda otro testimonio de la difusión y entusiasmo del público por el teatro, además del interés de su temática como fuente de inspiración por parte de los artistas. En la crátera, ${ }^{6}$ del 410 a.C., Odiseo y sus compañeros están a punto de cegar a Polifemo que aún duerme sin sospechar el engaño. La imagen no se inspira en el relato homérico, como podemos inferir por la presencia de dos Sátiros ejecutando el típico paso de la danza coral y dos jóvenes que iluminan la escena con antorchas del otro lado, sino en el Cíclope de Eurípides, escrita muy poco tiempo antes de la realización de este vaso. El curioso "tercer ojo" sobre la frente del gigante se explica así como un accesorio de la indumentaria dramática.

La crátera del Pintor de Pronomos, ${ }^{7}$ del 400 a.C., ilustra los momentos previos al desarrollo de un drama satírico. La realidad y el mito se entremezclan; Dionisos y Ariadna proclaman la necesidad de la intervención divina en el mundo del teatro, se ubican

(4) "Preparativos para un drama satírico". Pintor de Pronomos. Ilustraciones en Bieber (1937, Fig 20); Webster (1956, plate 8); Charbonneaux et al. (1970, Figs. 314, 315); Green and Handley $\left(1995, n^{\circ} 5\right)$.

(5) "Pandora". Pintor de los Niobidas. Green and Handley $\left(1995, n^{\circ} 3\right)$.

(6) "Odiseo y Polifemo". Pintor del Cíclope. Ilustración en Charbonneaux et al. (1970, Fig 340); Green and Handley
$\left(1995, n^{\circ} 10\right)$.

(7) Ver nota 4 
DUKELSKY, C.; MARTINO, A.M. Imágenes teatrales en la pintura de vasos griegos. Rev. do Museu de Arqueologia e Etnologia, São Paulo, 12: 71-79, 2002.

en el centro de una complicada escena en la cual todos los personajes están preparándose para honrarlos. Los miembros del coro, cuyos nombres aparecen escritos junto a cada uno, conversan despreocupadamente con sus máscaras en las manos. Se diferencian claramente de los actores protagónicos: los coreutas están semidesnudos, con sus falos aplicados y las máscaras satíricas, mientras los actores lucen lujosas y elaboradas vestimentas, y sus máscaras están trabajadas minuciosamente para expresar la psicología y el carácter individual del personaje que representarán. A la derecha del vaso se identifican claramente Heracles y el Paposileno. El héroe exhibe un atuendo muy decorativo, el pecho cubierto por una coraza dorada, porta la maza y la piel de león que lo caracterizan. El viejo sileno lleva el típico traje ajustado con motitas blancas y la piel de un animal salvaje sobre su hombro que recuerda sus estrechas vinculaciones con el mundo irracional de la naturaleza. Resulta elocuente el contraste que se establece entre las fisonomías triviales, casi idénticas, de los actores y la marcada expresividad de las máscaras que cubrirán sus rostros y ayudarán a manifestar las personalidades de los protagonistas ante los espectadores. Sólo un personaje está realmente actuando en esta pintura: uno de los coreutas, el que está bajo Dionisos, ya se ha calzado la máscara y levanta su pierna para iniciar el baile. ${ }^{8}$ Una situación similar transmitió el Pintor de Tarporley: ${ }^{9}$ dos personajes están aún sin terminar de vestirse, sus actitudes son naturalistas, humanas; el tercero ya ha asumido el papel satírico y adopta una pose juguetona y provocativa.

El drama satírico contiene elementos muy primitivos, aspectos grotescos que ayudaban a provocar la risa y la distensión después de la trilogía de tragedias. Los personajes debían ser divertidos y retozones a juzgar por los saltos grotescos que nos muestran las imágenes. $\mathrm{La}$ comedia implica un similar espíritu carnavalesco, subrayado por los atuendos extravagantes y los

(8) Alrededor del coreuta danzante otros dos importantes miembros del universo teatral: a un lado el escritor Demetrio, sentado con un rollo en la mano, quizás esperando ver representada su propia obra; del otro, y ubicado en un lugar de preeminencia - que nuevamente destaca la trascendencia de la música - el famoso tocador de flauta tebano Pronomos, quien ganó la competencia musical en el 394 a.C.

(9) "Actores preparándose para obra satírica". Pintor de Tarporley. Trendall (1989, Ilustración 104). gestos procaces de los actores. En una crátera ática ${ }^{10}$ del 415-400 a.C. dos personajes se enfrentan, separados por el infaltable intérprete de aulos en el medio. Los hombres con trajes de pájaros, decorados con motitas, al estilo Paposileno, llevan atados sus falos erectos como los interpretes de los dramas satíricos aunque en este caso sea posiblemente una comedia, Aves, de Aristófanes. Efectivamente, por el estilo, ubicamos esta obra un poco después del estreno de esta obra en 414 a.C. Sin embargo, el gesto entre burlesco y cacareador de los adversarios podría vincular esta escena con Nubes, también de Aristófanes. Una cita de un erudito de la Antigüedad describió a dos de los actores de esta comedia argumentando como gallos de riña y eso es exactamente lo que parecen los protagonistas de este vaso. Similar actitud graciosa exterioriza un actor cómico que personifica a Perseo en una cerámica del 420 a.C. ${ }^{11}$ El intérprete se ubica sobre un tablado de madera al cual se accede por una escalera, frente a él dos espectadores ¿Dionisos y Ariadna? completan el escenario. En contadas ocasiones los artistas griegos han ubicado a sus personajes en un contexto espacial específico; no forma parte de los objetivos esenciales la representación del paisaje, de un entorno urbano o de un interior. Sin embargo la temática teatral generó otros intereses y es realmente significativo que las fuentes antiguas citen, como precursores de las novedosas tentativas de representar la tercera dimensión a dos pintores, Agatarco y Apolodoro, quienes, además de pintores, fueron escenógrafos. Vitruvio menciona a Agatarco como autor de un tratado donde aparece la noción de líneas de fuga. Hacia mediados de siglo $\mathrm{V}$, la escenografía teatral tenía el aspecto de un pequeño palacio, decorado habitual de las tragedias, con columnas, pórticos y puertas laterales. Así lo vemos en fragmento de un vaso italiota de mediados siglo IV. ${ }^{12}$ Varios estudiosos identifican la obra representada como Peleo, tragedia perdida de Eurípides, fundamentalmente por la disposición de los personajes protagónicos delante del palacio y de los actores

(10) "Coro de gallos". Ilustración en Boardmann (1989, Fig. 314). (11) "Actor como Perseo" Vaso del 420 a.C. Ilustración en Webster (1956, Plate 14).

(12) "Escenografía teatral". Grupo de Konnakis. Ilustración Charbonneaux et al. (1970. Fig 360); Webster (1956, Plate 10). 
DUKELSKY, C.; MARTINO, A.M. Imágenes teatrales en la pintura de vasos griegos. Rev. do Museu de Arqueologia e Etnologia, São Paulo, 12: 71-79, 2002.

secundarios en el plano posterior. El edificio presenta características similares a la arquitectura religiosa, con su tímpano adornado por acroteras, aunque el pintor ha combinado las columnas jónicas con el friso de triglifos y metopas del orden dórico; curiosa combinación que atribuimos al vuelo de la imaginación creadora del artista como sucede en más de una ocasión entre los pintores de vasos. La escena está, con seguridad, vinculada al teatro, si los personajes no tienen ni máscaras ni disfraces es porque existe una marcada diferencia entre las representaciones de los dramas y de las comedias, y parecería que los pintores de vasos reaccionaron igual que los espectadores: el teatro serio requería mantener la ilusión dramática y persuadir al público de que los hechos que se desarrollaban en el escenario eran ciertos. Los actores recreaban historias heroicas o míticas, por lo tanto su atuendo, postura, voz y actuación debían estar acordes con cierta solemnidad y mesura. El pintor nos brinda imágenes donde el equilibrio de las formas, la nobleza de las actitudes y la armonía del conjunto son los elementos primordiales de la representación plástica. La comedia, en cambio, era un entretenimiento netamente popular, los actores se ponían disfraces apropiados para provocar la hilaridad: se colocaban aditamentos para figurar grandes genitales, máscaras grotescas, trajes con rellenos para acentuar gorduras deformantes y, como no podía haber elencos de mujeres, cuando los comediantes asumían roles femeninos los disfraces eran corrosivamente graciosos. El cuidado por lograr una apariencia femenina resultaba esencial para la verosimilitud de una tragedia, muy por el contrario, un cuerpo grotesco, la barba de varios días, sumado a los adornos femeninos aportaba más ingredientes a la diversión de la comedia. ${ }^{13}$ Así también las imágenes de los vasos que corresponden a obras cómicas apuntan a exagerar los defectos y fealdades llegando hasta la caricatura. La interacción que se daba entre el público de comedia y los actores, que generaba toda clase de exabruptos, se corresponde con esa imagen del actor cómico tan chocante e irreverente que vemos en los vasos; muy alejada de las tradicionales figuras equilibradas, armónicas y bellas de héroes y dioses.

(13) A modo de ejemplo, Pintor de Schiller. "Parodia de Telefo" 380-70 a.C. Ilustración en Green and Handley (1995, $\left.\mathrm{n}^{\circ} 27\right)$.
Un fragmento del "Grupo de Konnakis" de 350 a.C. que representa a un actor dramático con su máscara ${ }^{14}$ y la crátera apuliana con un grupo de actores bufones, del 340 a.C. ${ }^{15}$ nos dan la oportunidad de contrastar al cómico con el trágico. A punto de representar un personaje de la tragedia, el actor luce un traje sobrio y un rostro banal. Los pelos de su barba sin afeitar, una incipiente calvicie y las arrugas en la frente se borrarán rápidamente cuando se calce su máscara de rasgos ennoblecidos por un rostro serio, coronado por cabellos y barba blancos que indican la ilustre ancianidad del protagonista. Los actores bufones corresponden al teatro cómico típico de la Magna Grecia, la comedia fliácica, sumamente popular en esta época. ${ }^{16}$ Los pantalones ajustados debajo de sus túnicas dejan ver falos artificiales, resabios del disfraz satírico. Los rostros caricaturizados, los cuerpos panzones y el desparpajo caracterizan a los actores fliácicos quienes se burlan de los temas más sagrados. En este ejemplo, el personaje más joven se sienta, desfachatado, sobre un altar; en otros, Heracles, sinónimo de heroicidad en otro contexto, se burla risueñamente del rey de los dioses, ${ }^{17}$ quien, sentado en un trono demasiado alto, intenta vanamente lanzar su rayo; o Zeus aparece representado como un viejito enclenque, a punto de realizar una visita amorosa a Alcmena, que resultará frustrada porque su cabeza ha quedado trabada en la escalera. ${ }^{18} \mathrm{La} \mathrm{popularidad} \mathrm{de} \mathrm{las} \mathrm{obras} \mathrm{fliácicas} \mathrm{le}$ permite al artista tomarse licencias que estarían prohibidas en el caso de la tragedia.

A principios s. IV a.C. la producción de cerámica ática disminuye considerablemente, a causa del debilitamiento político y económico. En cambio en Italia meridional florece ${ }^{19}$ y se realizan

(14) “Actor dramático". Grupo de Konnakis. Ilustración en Bieber (1937, Fig. 216 a y b); Charbonneaux et al. (1970, Fig 368). (15) “Actores cómicos". Crátera apuliana. Ilustración Charbonneaux et al. (1970, Fig 367).

(16) La popularidad de la comedia fliácica fue tal que en la ciudad de Tarento sus habitantes ni siquiera se enteraron de la invasión romana en el 282 a.C., estaban todos divirtiéndose en el teatro.

(17) "Heracles se burla de Zeus". Pintor de Iris. Ilustración en Bieber (1937, Fig. 354).

(18) "Zeus y Alcmena". Asteas. Ilustración en Bieber (1937, Fig 368); Webster (1956, Plate 20).

(19) Trendall (1989) ha clasificado los talleres del sur Italia en: Lucania, Apulia, Campania, Paestum y Sicilia. En el taller de Paestum se destacaron dos grandes artistas, Asteas y Pitón. 
DUKELSKY, C.; MARTINO, A.M. Imágenes teatrales en la pintura de vasos griegos. Rev. do Museu de Arqueologia e Etnologia, São Paulo, 12: 71-79, 2002.

vasos, llamados italiotas, cuya temática se vincula a menudo con la actividad teatral. Así como la especialidad del teatro de la Magna Grecia fue el humor y la parodia, también los artistas se lucieron en las representaciones del teatro cómico, con pinturas graciosas y personajes divertidos que aún hoy provocan sonrisas.

El vaso del Museo de Tampa ${ }^{20}$ resulta interesante para analizar la problemática del rol femenino, desempeñado por los hombres. La tapa del vaso muestra dos cabezas una masculina, la otra femenina, ambos adornan sus cabellos; la mujer usa rodete, collar y aros. Estos dos perfiles, bellos y armónicos contrastan con la ridícula figura del actor fliácico, de cuerpo grotesco, cejas levantadas y un solo diente en su boca entreabierta. En la parte principal del vaso un actor se prepara para actuar, su cabeza con rodete y aros, es sospechosamente femenina. Mira coquetamente al espejo su rostro adornado que contrasta con su desnudez masculina. Cuando haya terminado de disfrazarse los espectadores estarán viendo a una mujer. En general, es difícil establecer en las imágenes cuáles corresponden a mujeres reales y cuáles a actores disfrazados de mujeres; salvo aquellos casos - como este - en los cuales se evidencia el momento de transición entre la realidad masculina y la ficción femenina. Observemos el vaso del Pintor de la Fiala (440-30 a.C.) con actores vistiéndose. ${ }^{21}$ La máscara femenina de uno de ellos está aún en el piso, mientras el actor se calza las botas altas que ocultarán su aspecto masculino, pero el otro ya está listo y si lo observáramos aisladamente, con nuestra mirada contemporánea, sería muy difícil no identificarlo como una verdadera mujer, como seguramente lo era para la audiencia griega antigua. ¿Estaba realmente prohibida la actuación femenina? Una crátera pintada por Asteas ${ }^{22}$ parece contradecirlo. Se trata de una acróbata, su cuerpo desnudo indica su femineidad subrayada por el blanco de su piel, color tradicionalmente asociado a las mujeres en la

(20) "Joven desnudo ante un espejo". Atribuido a Asteas, 340-320 a.C. Ilustraciones en el texto y en The Perseus Project. http://www.perseus.tufts.edu..

(21) "Actores vistiéndose como mujeres". Pintor de la Fiala. Ver ilustración en Bieber (1937, Fig. 108).

(22) "Acróbata femenina y actores fliácicos". Asteas. Ilustración en Charbonneaux et al. (1970, Fig. 371). pintura de vasos. Dos actores cómicos la acompañan, uno de ellos evoca el descaro de la comedia, mirando impúdicamente los pechos de la muchacha. Desde las ventanas se asoman actores con sus máscaras presenciando la escena junto con Dionisos, sólo él, como dios, representado según el arquetipo de belleza griego. Otro ejemplo de la Magna Grecia, ${ }^{23}$ muestra una mujer en un contexto teatral, la danzante bufona, de rasgos grotescos y cuerpo poco agraciado ejecuta un torpe paso de baile. Si no fuera por su desnudez podríamos fácilmente confundirla con un hombre. En este "mundo al revés" de lo cómico los roles sexuales se confunden o se invierten. Asteas ${ }^{24}$ juega, irreverente, con un tema heroico: en lugar de mostrar a la desesperada Casandra abrazada a la estatua de Atenea, es Ayax quien busca refugio para no ser violado por la heroína, que aquí es "la mala de la película". La alta intensidad dramática que en las tragedias tienen las escenas de refugio en el altar se convierte, en manos de la comedia fliácica, y en la pintura de Asteas, en un chiste.

La cantidad de cerámica pintada con escenas teatrales refuerza la idea de que las representaciones fueron eventos muy importantes para el Estado, que atraía numerosos visitantes de otras ciudades y que la producción de las mismas eran un esfuerzo que requería un fuerte sentido de compromiso hacia el teatro. Si en toda ciudad medianamente importante había un teatro, es lógico pensar que la cerámica alusiva debía tener mucha demanda ya que permitía a su poseedor el recrear constantemente y sólo a través de la mirada, la experiencia teatral que había disfrutado en alguna ocasión. El público adquiría estos vasos para rememorar lo que ya conocían; los artistas los pintaban para la gente que había visto las obras y que identificaba las escenas y los sentimientos que les habían generado. La visualización de escenas teatrales a través de los vasos nos permite hoy trasladarnos en el tiempo y convertirnos en modernos espectadores en un acercamiento casi mágico a situaciones ocurridas hace ya tanto tiempo. Desde luego debemos admitir que no podemos tener la absoluta seguridad de que las imágenes pintadas sean el correlato exacto de las representaciones teatrales, algunos detalles o incluso

(23) "Danzante bufona". Apulia. Ruvo. Ilustración en Charbonneaux et al. (1970, Fig. 369).

(24) "Ayax y Casandra". Asteas. Ilustración en Bieber (1937, Fig. 366). 
DUKELSKY, C.; MARTINO, A.M. Imágenes teatrales en la pintura de vasos griegos. Rev. do Museu de Arqueologia e Etnologia, São Paulo, 12: 71-79, 2002.

aspectos importantes de las representaciones podrían ser producto de la fértil inventiva de los artistas plásticos y no una repetición estricta del hecho escénico. Son, inevitablemente, una gran ayuda cuando reproducen imágenes que corresponden a tragedias o comedias perdidas pero debemos preguntarnos si la imaginación del pintor pudo llevarlo a desarrollar escenarios imaginarios o personajes accesorios que no aparecen en la obra literaria original. Como sucede frecuentemente tenemos más preguntas que respuestas y sóloel análisis exhaustivo de las piezas y de los textos podrán acercarnos a la verdad.

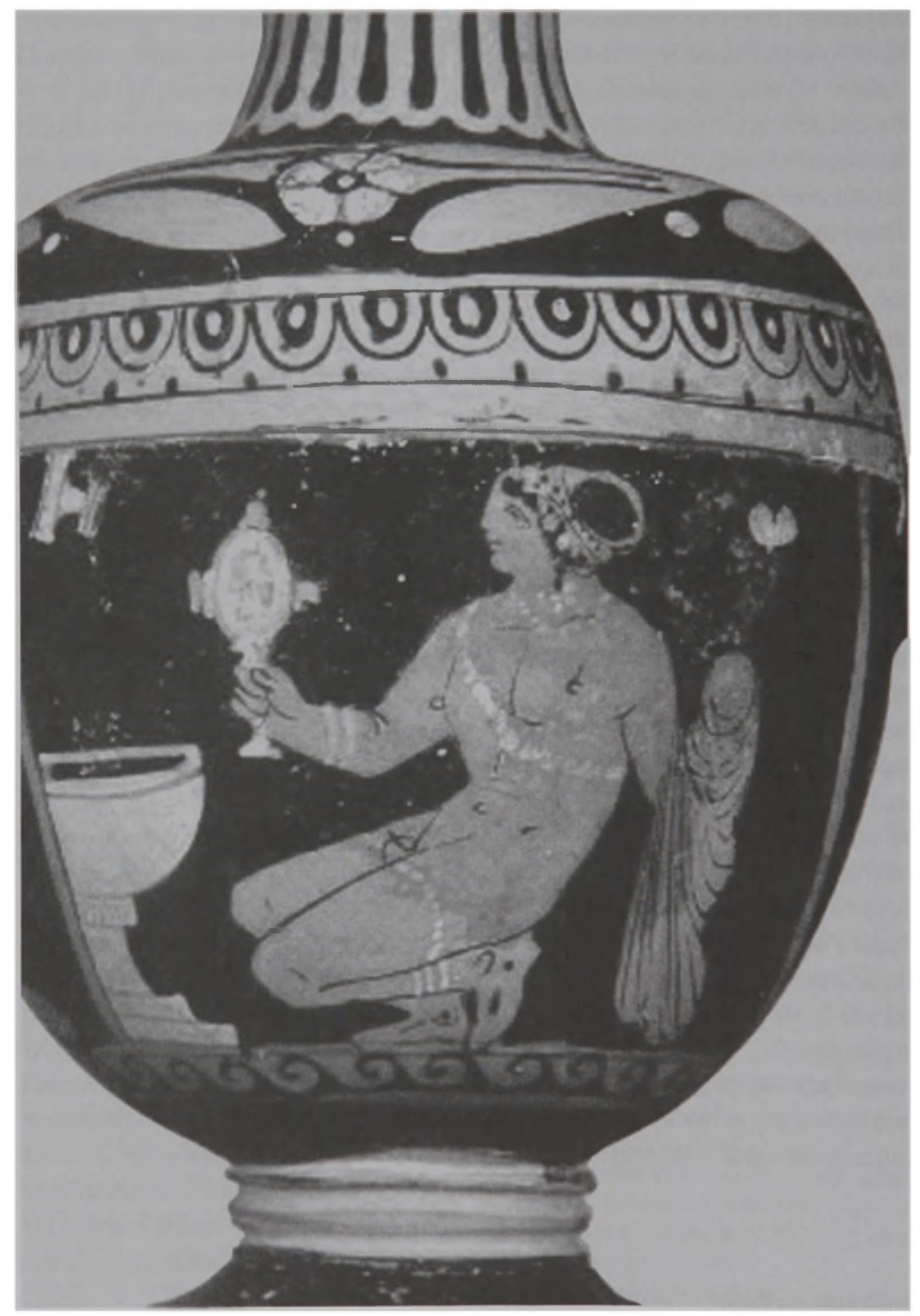

F ig. 1 - "Joven desnudo ante un espejo". Hidria-pyxis atribuida a Asteas, 340-320 a.C. Tampa Museum of Art. Tampa 89.98. Photographs by Maria Daniels. The Perseus Project. http://www.perseus.tufts.edu. 
DUKELSKY, C.; MARTINO, A.M. Imágenes teatrales en la pintura de vasos griegos. Rev. do Museu de Arqueologia e Etnologia, São Paulo, 12: 71-79, 2002.

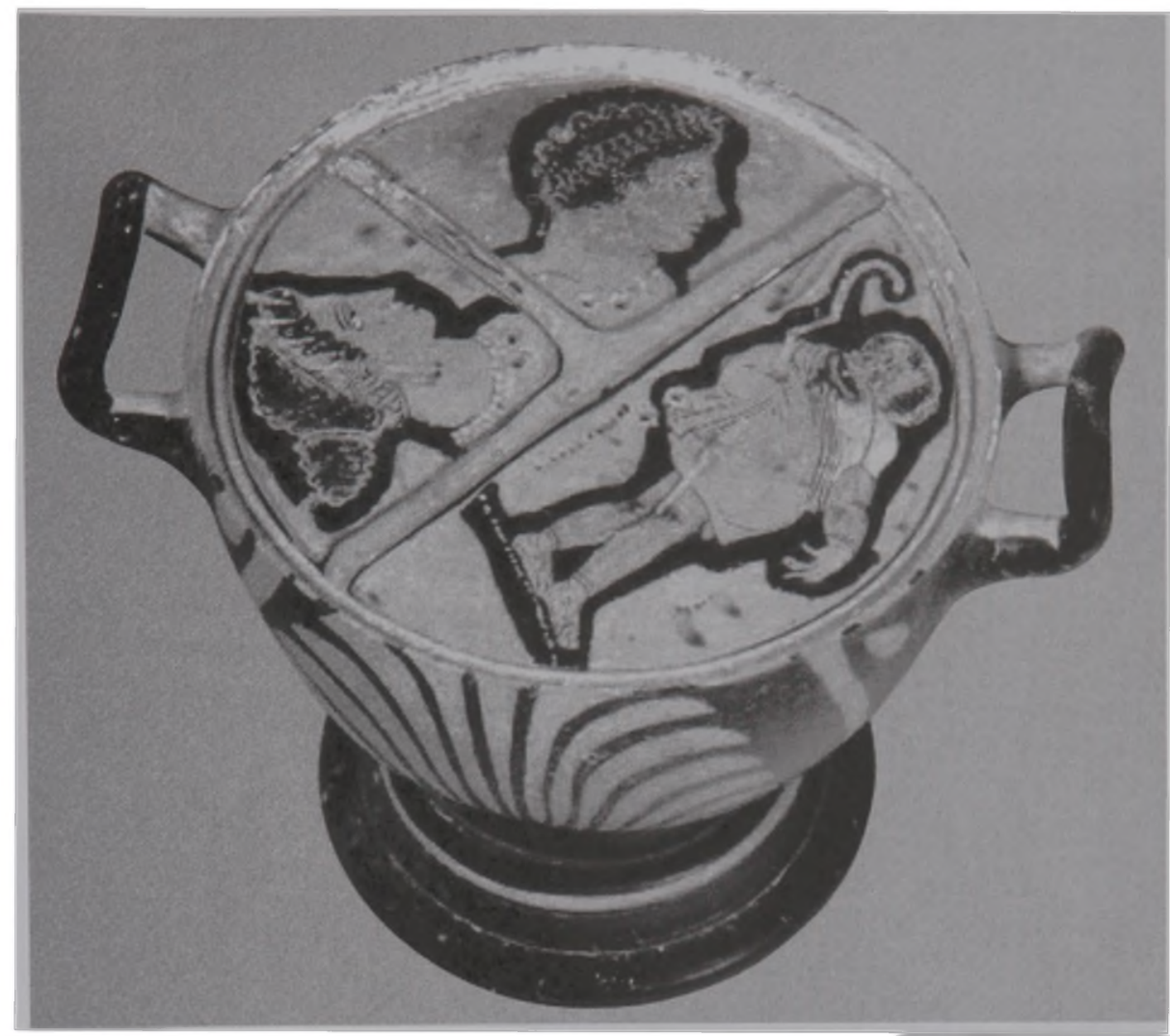

Fig. 2 - Tapa del mismo vaso con actor fliácico y dos cabezas, una masculina y la otra femenina.

Fig. 3 - Actor fliácico. Detalle del anterior.

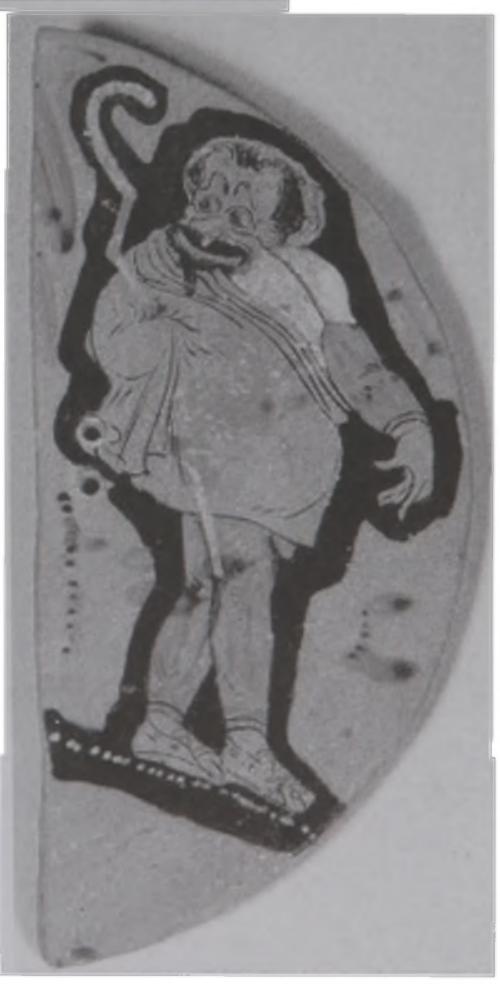


DUKELSKY, C.; MARTINO, A.M. Imágenes teatrales en la pintura de vasos griegos. Rev. do Museu de Arqueologia e Etnologia, São Paulo, 12: 71-79, 2002.

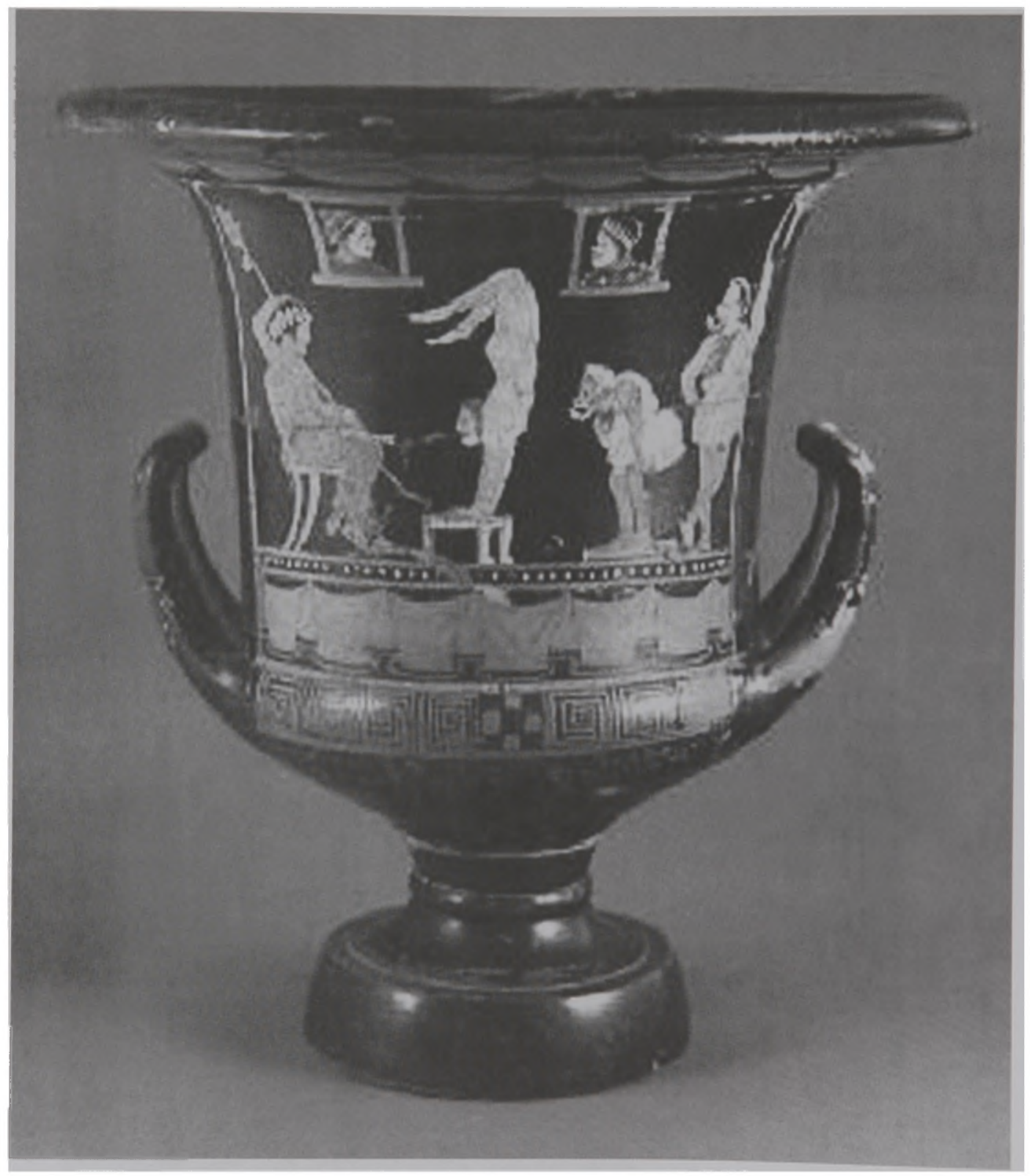

Fig 4 - "Acróbata femenina y actores fliácicos" Asteas. 
DUKELSKY, C.; MARTINO, A.M. Imágenes teatrales en la pintura de vasos griegos. Rev. do Museu de Arqueologia e Etnologia, São Paulo, 12: 71-79, 2002.

DUKELSKY, C.; MARTINO, A.M. Theatrical images in the painting of Greek vases. Rev. do Museu de Arqueologia e Etnologia, São Paulo, 12: 71-79, 2002.

ABSTRACT: The analysis of painting on ceramics, with images taken from the Greek theater, allows a partial reconstruction of the spectator's view in that society. The divergence between the images of tragedies and those of comedies is obvious, such as it happens in their written versions. Specially attractive are the grotesque and deformed figures, concordant with the irreverence and lack of inhibition characteristic of the comical genre. It is also of interest the figures of male actors playing feminine roles.

UNITERMS: Theater-Paintings - Comedy-Tragedy - Masculine-feminine.

\section{Referencias bibliográfícas}

\author{
BIEBER, M. \\ 1939 The History of the Greek and Roman Theater. \\ London, Princeton: University Press. \\ BOARDMAN, J. \\ 1985a Athenian Black Figure Vases. London: \\ Thames \& Hudson. \\ 1985b Athenian Red Figure Vases. The archaic \\ Period. London: Thames \& Hudson. \\ 1989 Athenian Red Figure Vases. The classical \\ Period. London: Thames \& Hudson. \\ CHARBONNEAUX, J. et al. \\ 1970 Grecia Clásica. Madrid: Aguilar. \\ GREEN, R.; HANDLEY,E. \\ 1995 Images of the Greek Theatre. London: The \\ Trustees of the British Museum.
}

\author{
LAWRENCE, A.W. \\ 1962 Greek Architecture. London: Penguin Books. \\ ROBERTSON, $M$. \\ 1978 La peinture grecque. Genève: Skira. \\ TRENDALL, A.D. \\ 1989 Red Figure Vases of South Italy and Sicily. \\ WEBSTER, T.B.L. \\ London: Thames \& Hudson. \\ 1956 Greek Theatre Production. London: Methuen \\ and Co.Ltd.
}

The Perseus Project. http://www.perseus.tufts.edu. 